\title{
PARTICULARITIES RELATED TO DRILLING OFFSHORE WELLS IN AREAS WITH VERY DEEP WATER
}

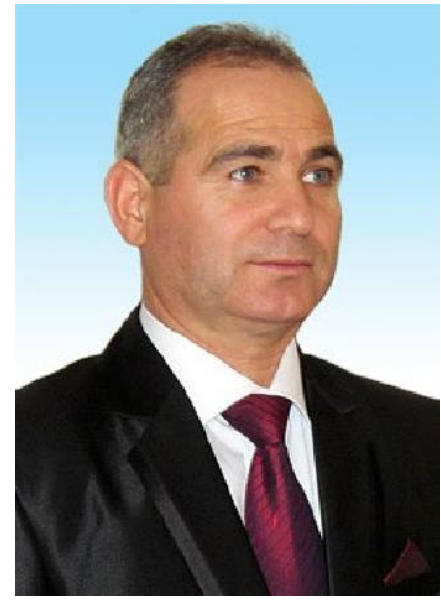

Valentin-Paul TUDORACHE $^{1 *}$, Associate Professor PhD. Eng. at Petroleum-Gas

University of Ploiesti, Vice-President of A.G.I.R.

Prahova branch.

E-mail: valentin.tudorache@ yahoo.com

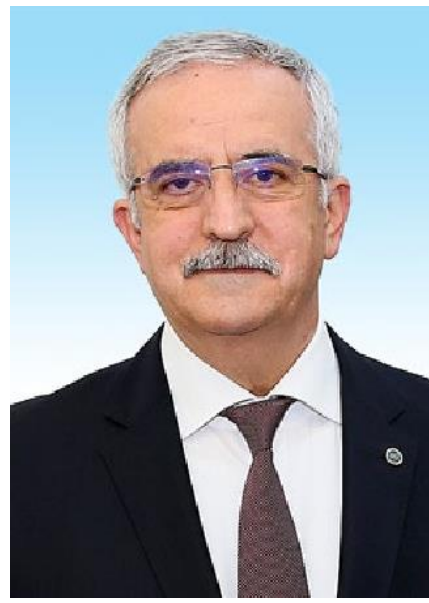

Mihail MINESCU ${ }^{1}$,

Professor PhD. Eng. at Petroleum-Gas University of Ploiesti, President of the Senate Petroleum-Gas University of Ploiesti, and Member of the Academy for Technical Sciences of Romania.

E-mail: mihail.minescu@ yahoo.com

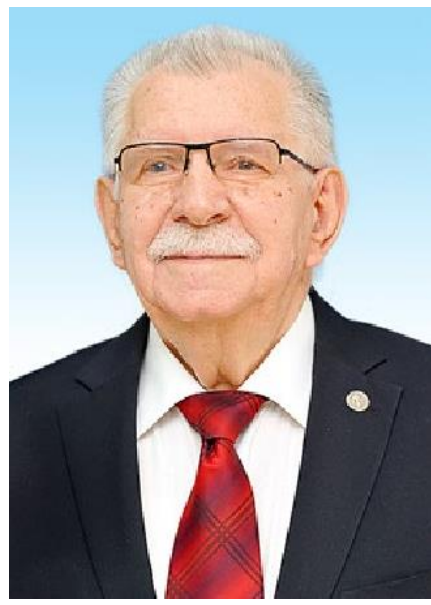

Nicolae ILIAS ${ }^{2}$,

Professor PhD. Eng. at University of Petrosani, Member of the Academy for Technical Sciences of

Romania,

President of the Section Oil, Mine and Geonomy Engineering.

E-mail: iliasnic@yahoo.com

The article presents an analysis of the realities faced by the operators in the oil industry, but especially the operators in the exploitation of the risers. Oil industry operators are focusing on drilling offshore wells to very deep water depths, as there are significant oil and gas resources that ensure high production. This analysis refers to the establishment of limit conditions that occur during drilling operations. We call this complex of factors the mechanics of riser. The article also refers to establishing the way of working in accordance with the API recommendations in force and obtaining theoretical results for offshore drilling in deep water.

*Автор для переписки. E-mail: valentin.tudorache@yahoo.com 
These results are the starting point for simulation with the help of specialized software and obtaining results useful for the exploitation of risers in drilling wells in deep water. Drilling activity in deep water can only be done with dynamically positioned platforms, such as semisubmersibles platforms and drillship.

KEY WORDS: very deep water, oil, gas, riser system, marine currents, pressure, temperature, effort, wave.

\section{ОСОБЕННОСТИ БУРЕНИЯ МОРСКИХ НЕФТЯНЫХ И ГАЗОВЫХ СКВАЖИН НА УЧАСТКАХ С ОЧЕНЬ ГЛУБОКОЙ ВОДОЙ}

В статье представлен анализ реалий, с которыми сталкиваются операторы нефотяной отрасли, но особенно операторы эксплуатации райзера. Операторы нефттяной отрасли сосредоточены на бурении морских скважин на очень глубокие глубины, поскольку имеются значительные запасы нефти и газа, которые обеспечивают высокую добычу. Этот анализ относится кустановлению предельных условий, которые возникают во время буровых работ. Мы называем этот комплекс фракторов механикой райзера. В статье также говорится об установлении способа работы в соответствии с действующими рекомендациями API и получении теоретических результатов для морского бурения в глубокой воде. Эти результаты являются отправной точкой для моделирования с помощью специализированного программного обеспечения и получения результатов, полезных для эксплуатации рейзеров при бурении скважин в глубоких водах. Бурение в глубокой воде может осуществляться только на динамически расположенных платформах, таких как полупогружные и буровые установки.

КЛЮЧЕВЫЕ СЛОВА: очень глубокая вода, нефть, газ, вертикальная система, морские течения, давление, температура, усилие, волна.

\section{СУЫ ӨТЕ ТЕРЕН АУМАҚТАРДА МҰНАЙ ЖӘНЕ ГАЗ ҰНҒЫМАЛАРЫН БҰРҒЫЛАУ ЕРЕКШЕЛІКТЕРІ}

Мақалада мұнай саласындағы операторлардың, әсіресе радиаторлардыпайдаланудағы операторлардың кез-келгенжағдайына талдаужасалды. Мұнай өнеркәсібінің операторлары теңіз ұңғымаларын бұрғылауға судың терең тереңдігін бұруға назар аударады, өйткені жоғары өндіруді қамтамасыз ететін маңызды мұнай-газ ресурстары бар. Бұл талдау бұрғылау жұмыстары кезінде пайда болатын шекті жағдайларды белгілеуге қатысты. Біз бұл фракторлар кешенін күлкі механикасы деп атаймыз. Мақалада сондай-ақ қолданыстағы API ұсыныстарына сәйкес жұмыс әдісін құру және терең суларда теңізде бұрғылау үшін теориялық нәтижелералутуралы айтылған. Бұл нәтижелермамандандырылған бағдарламалық қамтамасыздандырудың көмегімен модельдеудіңжәне терең сулардағыұңғымаларды бұрғылау кезінде мейіздерді пайдалану үшін пайдалы нәтижелер алудың бастапқы нүктесі болып табылады. Терең судағы бұрғылау әрекеті тек жартылай су асты және бұрғылау қондырғылары сияқты динамикалық орналасқан платформалармен жүзеге асырылады.

ТҮЙıн СөзДЕР: терең су, мұнай, газ, су жүйесі, теңіз ағымдары, қысым, температура, күш, толқын. 


\section{INTRODUCTION}

The offshore oil industry, hoses and risers are made with polymers with internal and external coatings, which provides fluid flow through the inner and outer insulation in relation to the marine environment. These polymers have a certain permeability to gas that can facilitate the reduction of the potential damage mechanisms of the life of the steel layers located between the pipe and the outer shell of polymer. The destruction mechanisms associated with water condensation, therefore, they must be removed.

This presentation describes a model used to study gas diffusion through layers of flexible pipes by time. The temperature gradient pipe is considered as temperature dependent permeability rates. This model is coupled with a calculation that indicate changes in pressure and volume of vapors resulting in the annular space. Associated mathematical models and methods for solving the results obtained are presented in Math CAD with a user-friendly interface that helps in data entry and processing results.

In this article will show the possibilities of this software.

\section{OPERATING ENVIRONMENT FOR RISER PRODUCTION}

A significant volume of oil resources is stationed in areas in deep water and very deep, the depth limit of the current work. The rapid development of methods for exploration and production in deep waters, registered in the last decade concludes that, once reached a record operating in deep water, it is immediately overcome.

They are considered deep water activity in terms of oil, waters deeper than $400 \mathrm{~m}$; $1500 \mathrm{~m}$ is considered very deep water (over $1600 \mathrm{~m}$ after MMS - MineralManagement Service, USA).

First of all, there are many types of offshore rigs, from example Figure 1 illustration shows just three main categories [1].

Oil industry operators are turning to large water depths, because there are significant resources that ensure high yields. Some oil wells in these areas can produce $8000 \mathrm{~m}^{3} /$ day crude oil production justifying additional costs and risk.

From example, projects operating from premises situated in water depths of $2000 \mathrm{~m}$
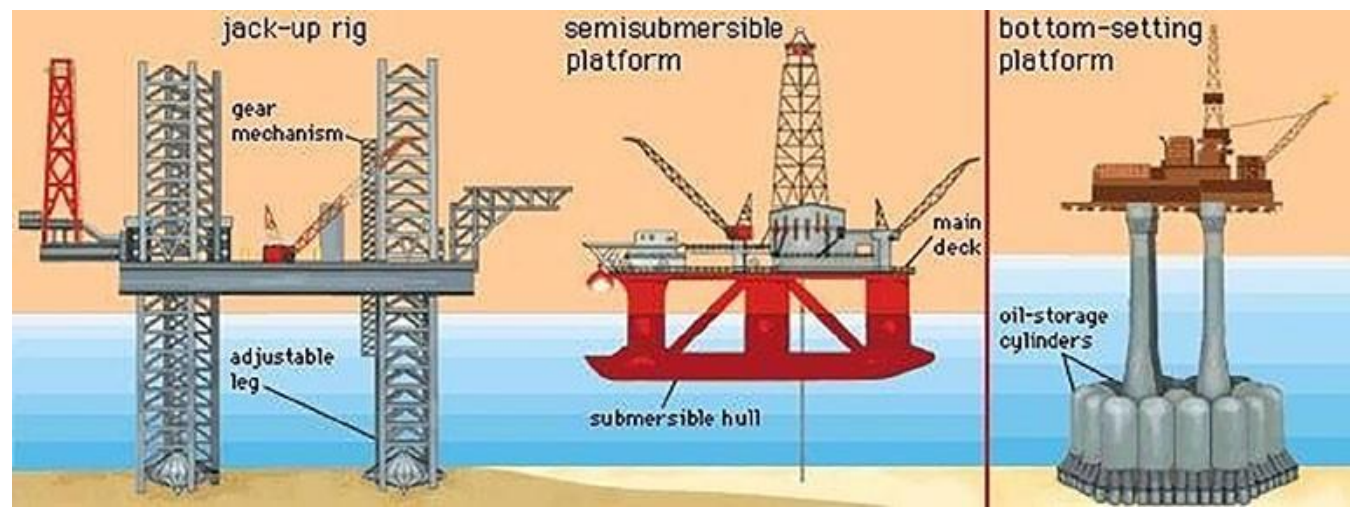

Fig. 1. - Types of offshore ries [1] 
in the Gulf of Mexico, Brazil and West Africa Offshore were unimaginable not long ago. A large number of wells have been drilled at depths of water; record of 10,400 $\mathrm{ft}(3,174$ m) was passed in February 2013 in the Indian Ocean.

The most important aspects in production wells located in deep water depths are related to very water, but also on the bottom, the hostile environment in which it operates:

- Waves 30 meters high;

- Winds exceeding 80 knots $(148.2 \mathrm{~km} / \mathrm{h})$;

- Low air temperatures: $-15^{\circ} \mathrm{C}$;

- Sea water temperature: $0^{\circ} \mathrm{C}$;

- Marine currents 3 knots $(5.5 \mathrm{~km} / \mathrm{h})$.

Very deep water development systems in addition to the developing technologies for exploration and production of oil and natural gas, new concepts in deep water systems and facilities have emerged to make very deep water projects a reality (see Figure 2) [2].

With wells being drilled in water depths of 10,000 feet, the traditional fixed offshore platform is being replaced by state-of-the-art deep water production facilities.

SPAR Platform (SPAR) consists of a large diameter single vertical cylinder supporting a deck. It has a typical fixed platform topside (surface deck with drilling and production equipment), three types of risers (production, drilling, and export), and a hull which is moored using a taut caternary system of six to twenty lines anchored into the seafloor. SPAR's are presently used in water depths up to 3,000 feet, although existing technology can extend its use to water depths as great as 7,500 feet.

Floating Production System (FPS) consists of a semi-submersible unit which is equipped with drilling and production equipment. It is anchored in place with wire rope

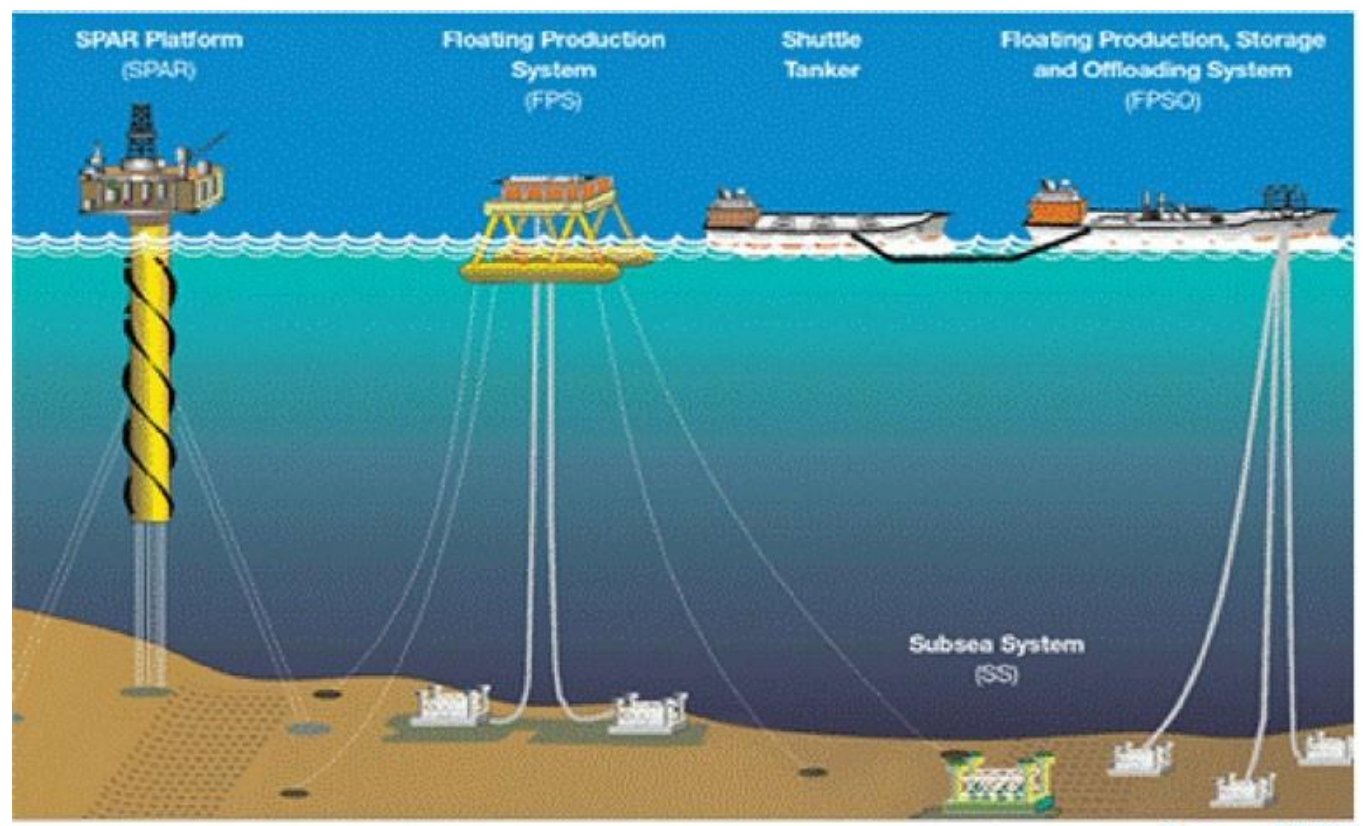

Fig. 2. - Floating production and subsea systems [2] 
and chain, or can be dynamically positioned using rotating thrusters. Production from subsea wells is transported to the surface deck through production risers designed to accommodate platform motion. The FPS can be used in very deep water.

Subsea System (SS) ranges from single subsea wells producing to a nearby platform, FPS, or TLP to multiple wells producing through a manifold and pipeline system to a distant production facility. These systems are presently used in water depths greater than 5,000 feet.

Floating Production, Storage \& Offloading System (FPSO) consists of a large tanker type vessel moored to the seafloor. An FPSO is designed to process and stow production from nearby subsea wells and to periodically offload the stored oil to a smaller shuttle tanker. The shuttle tanker then transports the oil to an onshore facility for further processing. An FPSO may be suited for marginally economic fields located in remote deep water areas where a pipeline infrastructure does not exist.

SPARs Platforms (SP), Floating Production Systems (FPS), Subsea Systems (SS) and Floating Production, Storage and Offloading systems (FPSO) are now being used offshore drilling in water depths exceeding 1,500 feet.

All of these systems are proven technology, and in use in offshore production worldwide.

\section{FLEXIBLE PIPES, FLEXIBLE RISERS AND HYBRID RISER SYSTEM}

\subsection{Flexible pipes}

While flexible pipe usage has spread in the oil industry during recent years, upstream petroleum engineers, generally, view it as a tool that in some few instances can save time or money [3].

Flexible pipe today may hold the key to overcoming one of offshore drilling's greatest very deep water hurdles caused by the close proximity of fracture gradient and pore pressure in very deep water (see Figure 3). Beyond about 7,500 feet waters, this phenomenon makes traditional well control all but impossible because, simply put, mud sufficiently

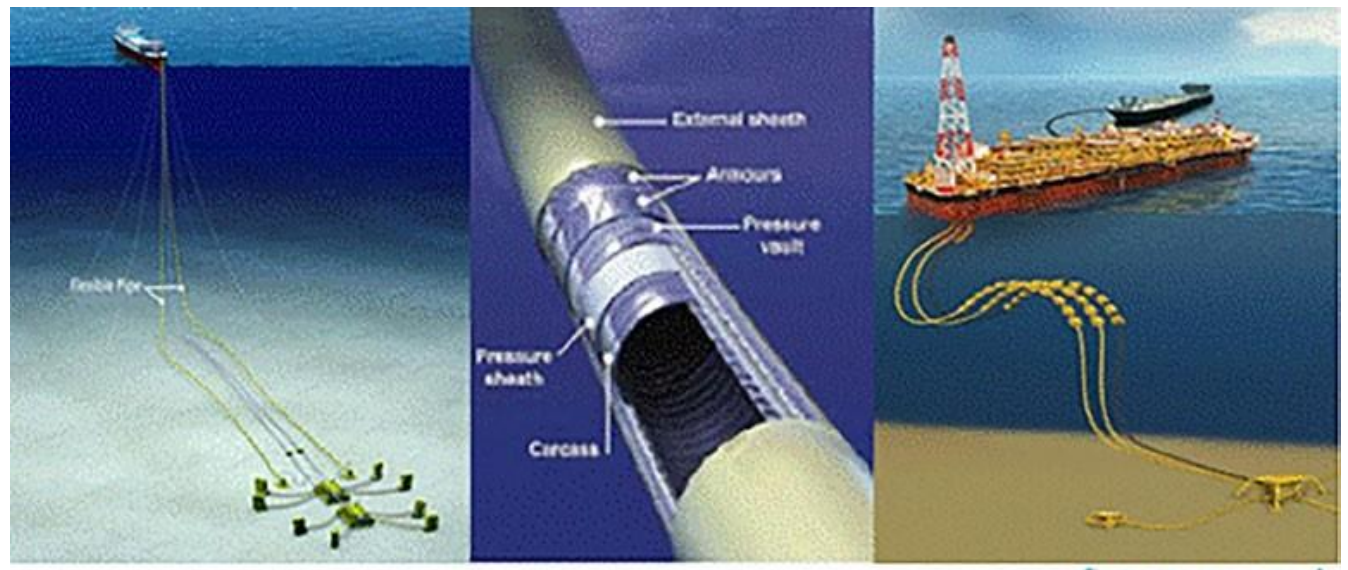

Soro ces: หาเา: gocgle

Fig. 3. - Typical flexible pipe structure [3] 
heavy to contain formation pore pressure is also very nearly sufficiently heavy to fracture it and one fluctuation will indeed do that.

Flexible pipe holds two very strong attractions as risers for floaters. First it is considerably lighter than rigid pipe and is neutrally buoyant. That means the vessel's limited space and buoyancy capabilities can be used for storage capacity or topsides processing facilities rather than to support thousands of feet of heavy steel pipe.

\subsection{Flexible risers}

Composed of multiple spiral laid materials as shown in Figure 4, the flexible riser demonstrates excellent bending capacity while still possessing exceptional strength, making it extremely versatile with regards to application. Originally designed for flowline applications between vessels, the flexible riser has gained popularity in deep water due to its ability to withstand significant dynamic environments making it an excellent choice for harsh sea conditions [3].

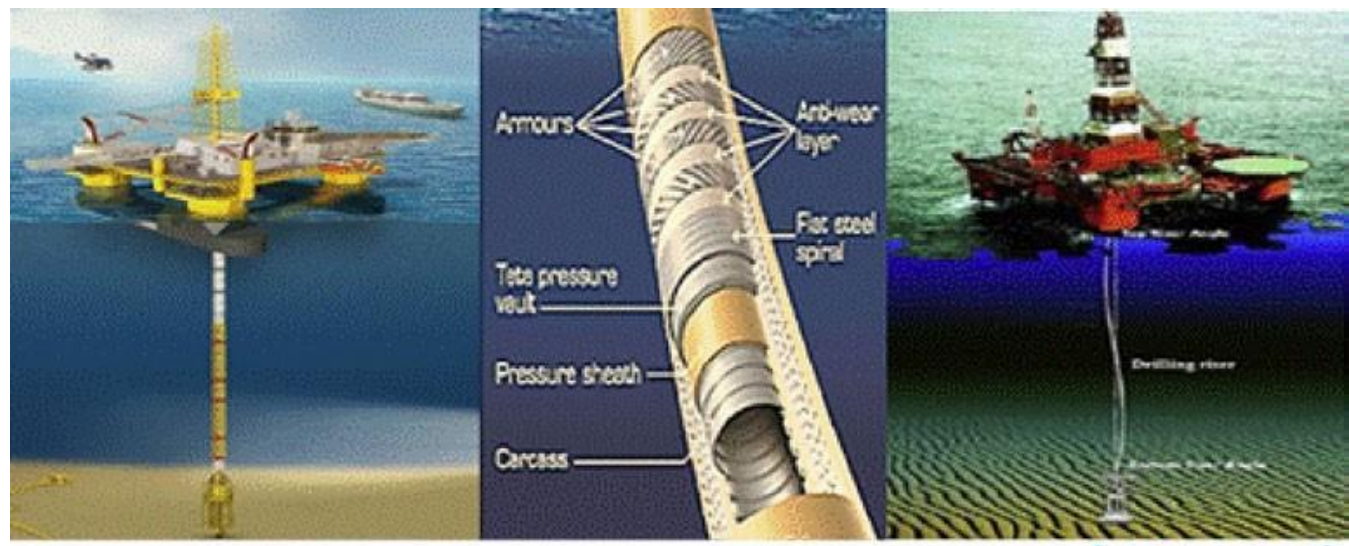

Fig. 4. - Topical flexible riser structure [3]

The ability to be wet stored (material choice permitting) prior to installation also proves a benefit of the flexible pipe in that it allows for schedule flexibility during an offshore installation campaign.

\subsection{Hybrid Riser System}

A top tensioned riser and hybrid riser tower, in Figure 5, is a vertically oriented riser (either flexible or steel pipe) commonly associated with tension leg platforms and spars. Utilizing buoyancy cans or hydro-pneumatic tensioners, large tensile forces are placed on the riser holding it in position for production. By utilizing such top tensioning devices, the risers are allowed to axially translate, or stroke, with respect to the platform motions.

There are a number of configurations for flexible risers, including the "steep $S$ " and "lazy S" that utilize anchored buoyancy modules, as well as the steep wave and lazy wave that incorporates buoyancy modules.

A hybrid riser system that can accommodate a number of different situations, flexible risers can withstand both vertical and horizontal movement, making them ideal for use with floating facilities. This flexible pipe was originally used to connect production 


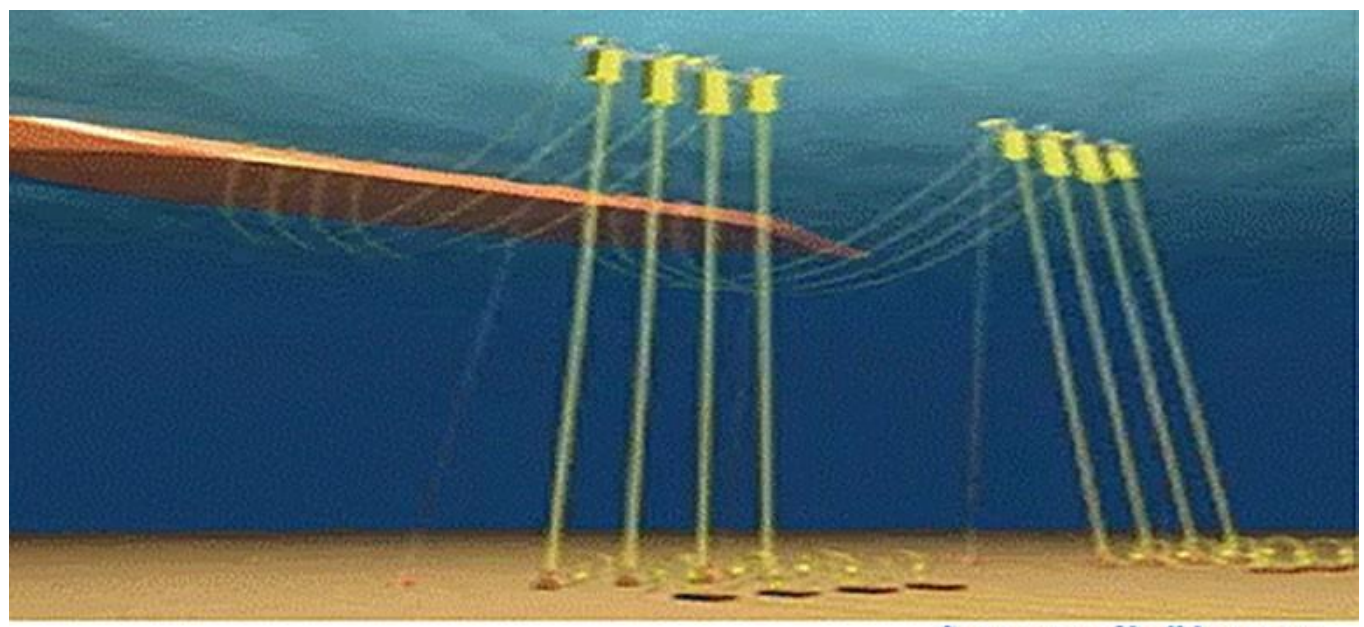

Sursa: warm. 2hoffshore com

Fig. 5. - Hybrid Riser System [4]

equipment aboard a floating facility to production and export risers, but now it is found as a primary riser solution as well [4].

Flexible risers manufactured from composites help to reset the equation, providing the required structural capacity without the weight gain.

With recent advances in composite materials and the extreme requirements of very

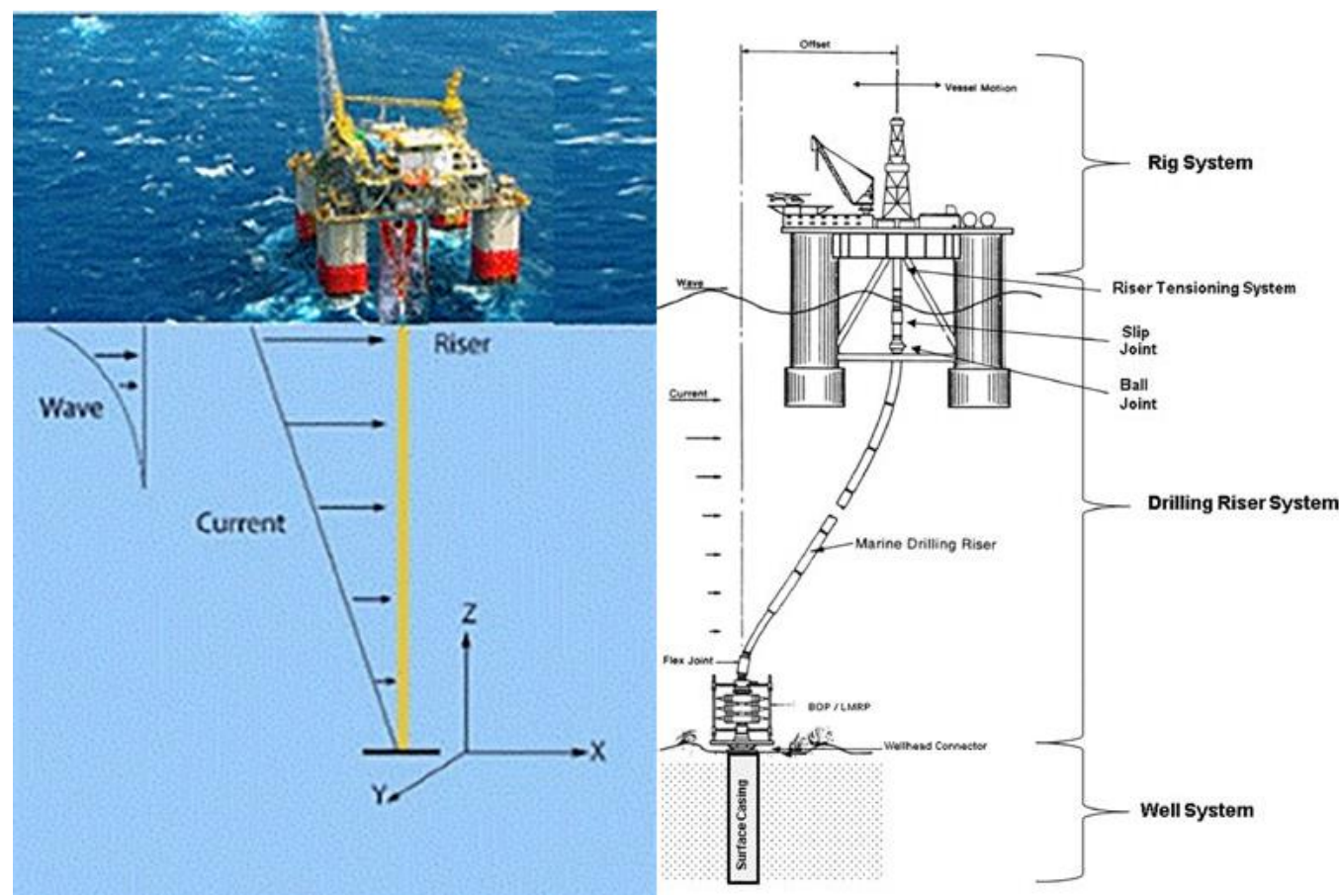

Fig. 6. - Topical drilling riser system and its sub-systems and components [5] 
deep water, however, flexible riser and flexible pipe may soon be recognized as an enabling technology rather than a convenient innovation.

In Figure 6 is represented one typical drilling riser system and its sub-systems and components.

Successful exploitation of the majority of floating production systems (rig system, riser tensioning system, drilling riser system, and well system) depends on good performance, systems dynamic flexible riser. The limits are consistently for wave, marine currents, higher pressures and higher temperatures (HPHT) for very deep waters, leading to increasing demands on the performance of pipe components.

The length of the riser is dependent on water depth and configuration of the column, which may be vertical or a variation waveform. Derivatives may be flexible or rigid and contained in the operating area of a fixed or floating platform installation type.

\section{THE STRUCTURE, THE DESIGN SPECIFICATIONS AND THE SELECTION CRITERIA OF THE RISER [6]}

Unbonded flexible pipes over the last 30 years were a key component in the production of oil and gas offshore. They represent an alternative to rigid steel pipes where they have the advantage of a quick installation and the potential adaptation for schimbăride route. These benefits often make unbonded flexible pipes, a more economic solution than rigid steel pipes.

Layers of steel materials are decisive for their behavior in acidic environments static and dynamic applications.

Unbonded flexible pipe structure requires that the steel is in direct contact with the fluid product. The medium is determined by permeation of small molecules (mainly $\mathrm{H}_{2} \mathrm{O}$, $\mathrm{CO}_{2}, \mathrm{H}_{2}$ and $\mathrm{CH}_{4}$ ) by lining the polymer. Predictions therefore operating environment is a key issue for the prediction, design and service life of flexible pipes.

Unbonded flexible pipes are made of concentric layers of polymer material and steel. In order to preserve the flexibility of the construction of the pipe layers are not bonded together. Different types of flexible unbonded pipe may omit some of thelayers.

The riser column is a complex construction aimed to ensure the connection between the well head and the drilling unit. The functions of this assembly are complex and are not limited only to ensure the space necessary for cuttings removal from the well. As the water depth increases, the working conditions of this assembly becomes challenging due to the complex forces and extreme environmental conditions which are impacting the operational mode as well as the stability.

\subsection{Structure - General items [6]}

In Figure 7 is presented in the most general description of each of the major layers. Therefore,

External thermoplastic sheath (a layer of extruded polymer) function is to protect steel components pipe from the outside (often seawater) and to provide mechanical protection.

Pressure armour layer:

A number of layers composed of helically wound wire form $\mathrm{C}$ of steel and/or metal strips. The layers of reinforcement provide resistance to radial loads. 


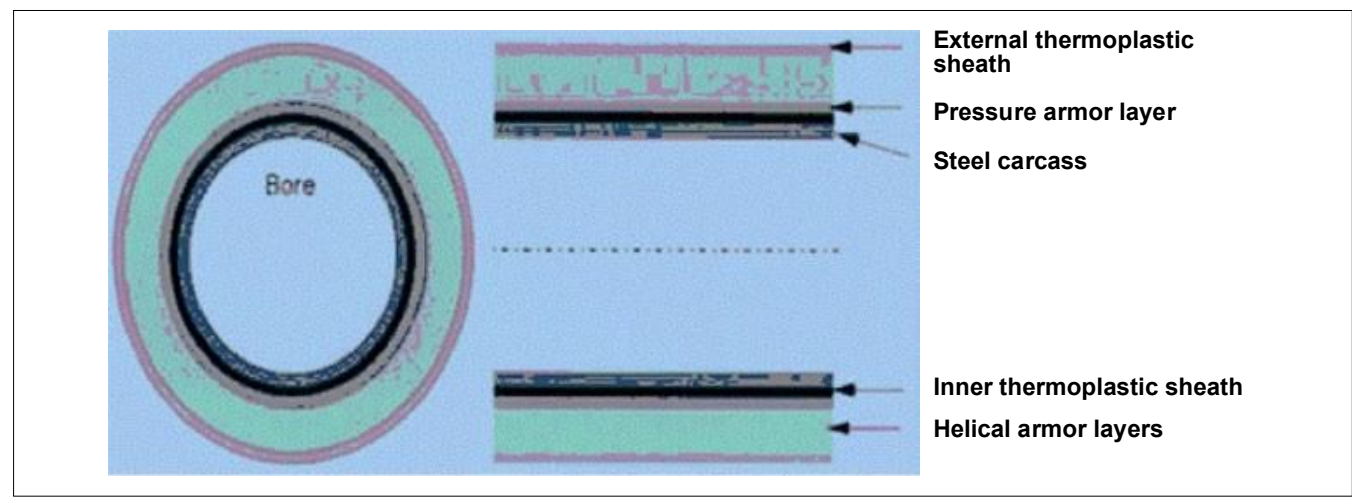

Fig. 7. - Structure-General items [6]

Steel Carcass:

An interlocking layer made of a stainless steel strip. The casing prevents the collapse of the inner hull and provides mechanical protection against gear (pigging) and abrasive particles. Quality stainless steel structure is studied in detail, but is outside the scope of this paper research.

Inner thermoplastic sheth:

A polymer layer extruded ensure the integrity of the internal fluid. Common types of polymers are polyethylene (PE), cross-linked polyethylene (XLPE), polyamide 11 (PA11) and Polyvinilien fluoride (PVDF).

\section{Fittings traction:}

A number of structural layers consisting of helically wound flat steel wire. Layers are against and wrapped in pairs. The layers provide resistance to axial loads.

\subsection{Design specifications [6]}

The annulus of flexible conduit, armored steel wires are located in specific geometric conditions: gap between armor is very small relative to the surface of steel wires $(0.03$ $<\mathrm{V} / \mathrm{S}<0.06 \mathrm{ml} / \mathrm{cm}^{2}$ ).

If the annular free space can be filled with seawater or condensation, corrosion conditions are limited due to report confinement (V/S) between volume (V) electrolyte and exposed surface (S) steel wires.

It is important to continuously improve performance to meet flexible pipe production in oil and gas operating conditions increasingly severe. This means that attention is turning to the design principles applied by the performance characteristics of the materials used (especially polymers) and the means of production.

Pressure polymer layer is an important component in the construction of pipelines to make flexible function pipeline leak resistance. A resin designed to be user is introduced as a barrier to isolate the high pressure hoses temperature/high pressure (see Figure 8).

The resin is finally selected a modified PVDF hpolimer. Material characterization was conducted entirely in compliance with applicable API standard. It confirmed the excellent behavior of mechanical strength, chemical, aging resistance, dimensional stability and low fluaju compatible with performance requirements.

Flexible pipes are composed of a succession of layers and layers of thermoplastic 


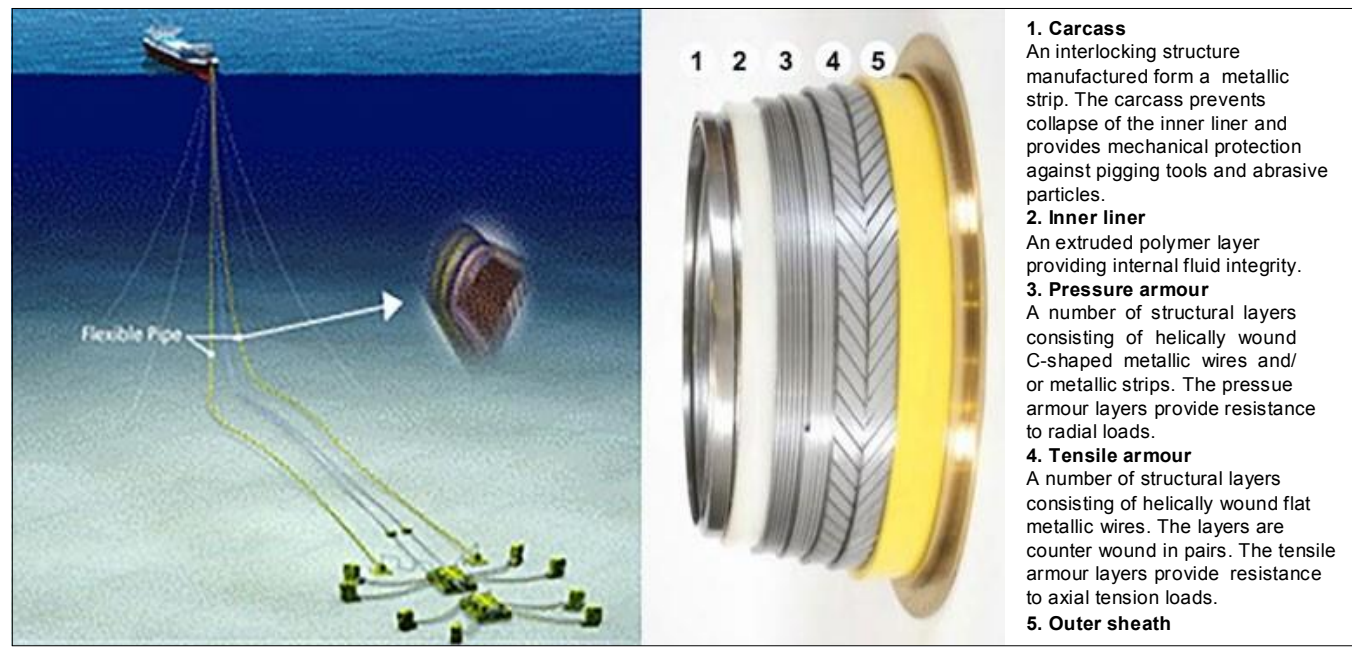

Fig. 8. - The structure ofa 3exible pipe element [6]

extrusions steel/armored spiral (see figure below), each layer being designed to withstand a specific charge. The combination of the water or sea water, $\mathrm{CO}_{2}$ and $\mathrm{H}_{2} \mathrm{~S}$ gases resulting infiltrated in a corrosive environment can cause stress corrosion cracking, hydrogen-induced cracking, pitting, general corrosion, or in the dynamic risers, to corrosion fatigue.

An important aspect which has to be taken in to consideration during this design stage is the determination of the optimal weight of the riser column in the water. As a matter of fact, the correct assessment of the buoyancy elements and correct positioning of those can ensure an optimal stability of the riser column. A neutral position can be obtained in order to achieve a reduction of the top tension as this is important for the tensioning system. However, there is a down side in this scenario: the lower tension can increase and this will result in overloading the well head.

The riser column can be considered a tube with high thickness walls which is impacted by different type of loads (for example, shear forces, compression etc.)

The forces acting over the riser column can be evaluated by using Tresca \& Von Mises relations and the result have to comply with acceptable limits of the materials composing the riser column [7].

Tresca criterion, also named the maximum shear stress criterion. It states that yielding will begin when the

maximum shear stress at a point is equal to the stress at yield when subjected to uniaxial tension or compression. For plastics, the yield strength in compression is often a lot higher than the yield strength in tension.

Von Mises stress criterion, also named the distortional energy density criterion states that "yielding begins when the distortional strain energy density at a point equals to the distortional strain energy density at yield in uniaxial stress". Meaning if the energy that is resulting in a volumetric change and shear in a body is too high, the element will fail. This way to look at stress will consider the volumetric change in the body. 
In three dimensions the Tresca and Von Mises yield surfaces will shape a hexagonal and a cylinder,

both with direction (see Figure 9).

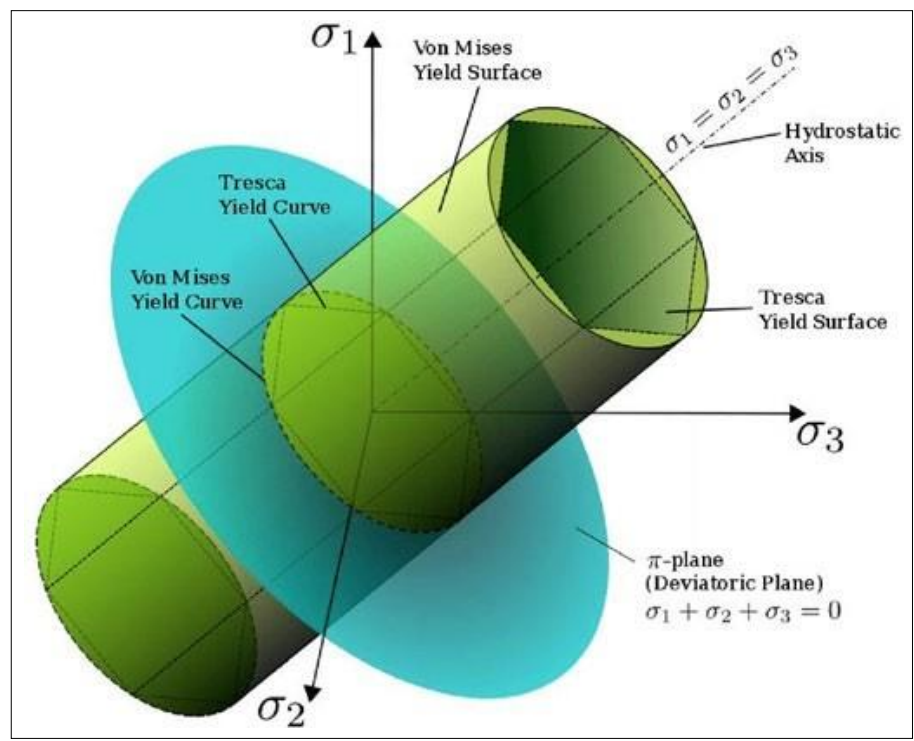

Fig. 9. - Tresca and Von Mise 3D curves, applied tor a riser section [7]

With hydrostatic axis as center where all principal stresses are the same. The deviatoric (effective) face or $\pi$-plane is angle $90^{\circ}$ on the hydrostatic axis $(\pi$-plane is the face where the sum of all the principal stresses are zero).

Moreover, the requirements for the top and lower tension must be verified in order to ensure the riser column stability for all operational phases, emergency situations included. As first step in this direction should include stability verification of the riser column towards limit conditions which may comprise of:

- Maximum water depth

- Maximum mud density

- Environmental conditions in connected mode

Moving forward, if the first condition has been fulfilled, the vertical deviation of the riser column must checked against requirements as well as fulfilling safety operational conditions, regardless the factors which may affect this. The API 2RD recommends a structural and dynamic analysis of the riser column if is considered that the operational environment impose further risk increase. Special simulations will be completed with a dedicated software, usually installed onboard the drilling units, in order to evaluate the vertical deviations of the riser column.

\subsection{Challenges related to optimization design}

Design challenges related to the use of flexible pipes in deep water are well known (ISO 13628-11). Thus, some of them listed below:

- The outside diameter greater because of the level high isolation;

- Increased resistance on: 
- Hydrostatic pressure;

- Breaking fatigue;

- Torsion and compression.

- The mechanical properties suitable working arrangements.

The very deep water challenges are the high hydrostatic pressure, prediction of riser loads and response, flow assurance, increased top-tension, and designing for economical installation. For drilling, an additional challenge is the ability of the formation to withstand pressure from the enormous weight of mud in the riser.

It should be pointed out that the presence of the two coatings of plastic on top of the insulation slows down the process of condensation of vapor in the annular space and thus reduce the water content condensed. The amount of water accumulated in the annular steel ring fused generates a $\mathrm{CO}_{2}$ partial pressure of $\mathrm{H}_{2} \mathrm{~S}$ in the armature respectively.

Factors influencing the integrity and life of:

a) INTERIOR factors affecting the integrity riser:

- Fatigue fracture of steel casing deformation housing;

- Aging in action chemical factors temperature water;

- Diffusion in the annular space of $\mathrm{H}_{2} \mathrm{~S} / \mathrm{CO}_{2}$;

- Influence of thermal variation;

- $\quad$ Fatigue protective coatings;

- The formation of hydrates;

- Erosion.

b) EXTERNAL factors affecting the integrity riser:

- Wear resulting from the interaction with the plant surface and submerged constructive elements;

- Deterioration protective outer covering;

- Interacting with other lines submerged;

- Normal wear constructive materials;

- Hydrogen cracks action;

- Corrosion;

The riser survey demonstrated that riser contractors are actively engaged in design and development of a variety of innovative, robust, and competitive new riser systems, as well as improving the existing systems.

Riser solutions have evolved to the point that the challenge now is how to select the best riser solution for the application

\section{ACTION OF DIFFERENT FORCES OVER THE RISER COLUMN}

The riser column can be represented as a beam connected at both ends with a spherical articulation. The various axis movement of the drilling platform are compensated by dedicated equipment (telescopic riser, upper flex joint and tensioner ring) in order to maintain the drilling unit on the position. The linear weight of the riser is the difference between the linear weights of the joint in water minus the linear thrust exerted through the thrust collar by the buoyancy elements that are dressing it.

The internal pressure generated locally by the mud column is equal to the mud specific 
gravity multiplied by the local column height. The external pressure generated locally by the sea water is equal to the sea water specific gravity multiplied by the local water depth. It has to be noted that what acts against the walls of the riser joints is the local difference in between the above two terms [8].

In the usual case of a riser string full of mud, the higher the mud weight $\&$ the water depth, the higher the differential pressure on the bottom that tends to "inflate" the joints generating hoop stress.

Should the riser for any reason be partially empty (mud heavy losses due to weak down hole formation), the riser wall would be subject to the external pressure only in the void zone.

The hydrodynamic forces of the waves will impact the riser column on the upper part and this is evaluated with MOJS equations (Morison, O'Brien, Johnson and Schaaf) [8].

The resistance of the riser column in to the water due to the oscillations is proportional with:

- A drag coefficient (friction, wake and added mass);

- The density of the sea water;

- The cross section of the riser string.

This approach is valid only if the current value is up to two knots. If this value is exceeded, the vortex phenomenon occurs, which generate vibrations in combination with the wave movement. The transversal vibrations are depending on the value of the tensions which are propagating along the riser column.

In Figure 10 is represented actions of the different forces (internal and external) over to which the riser column is subjected: the action of waves; the action of marine currents; the own weight of the riser column; the differential pressure of seawater and mud column, and, the upper and lower tension.

A riser system is much more than just a pipe. Design of a riser system for very deep

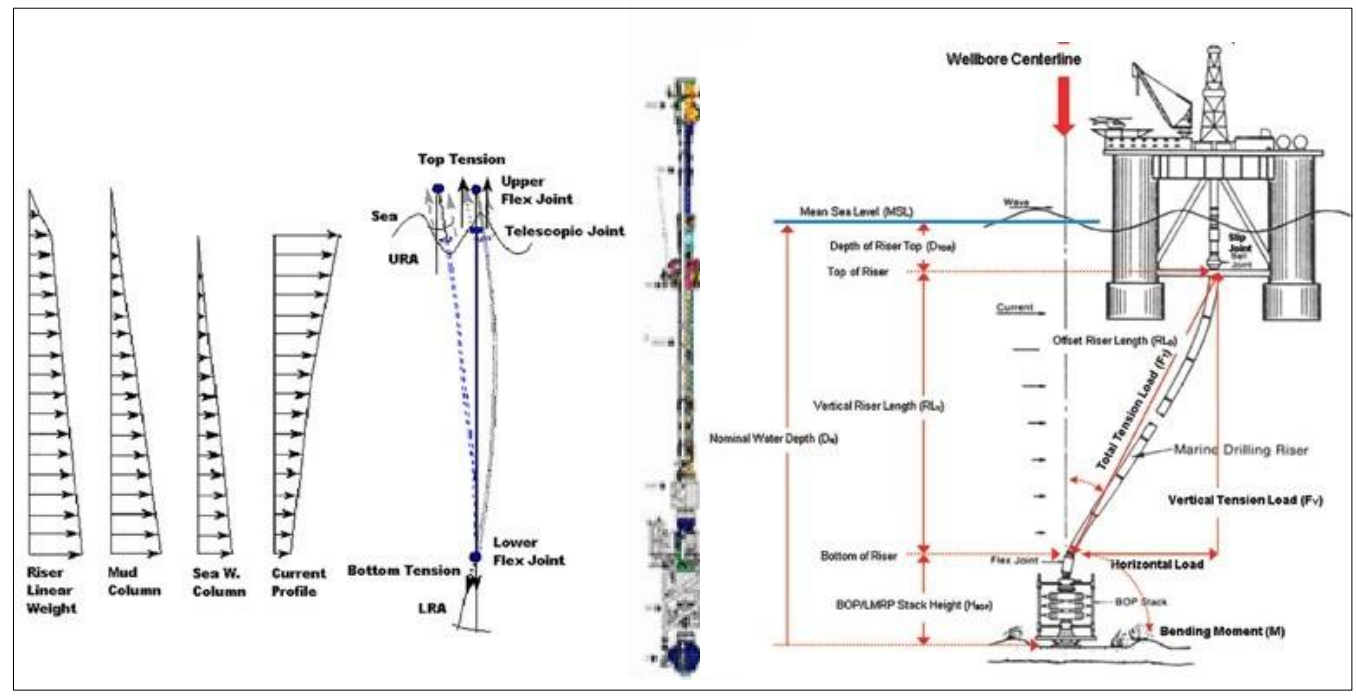

Fig. 10. - Tresca and Von Mise 3D curves, applied tor a riser section [7] 
water is a complex iterative multi-discipline process, with many variables. Depending on field layouts, vessel interfaces, fluid properties, and environmental conditions, a riser system is engineered for each particular application supported by prerequisite analysis, material, and testing pre-qualification [9].

If those conditions are exceeding the acceptable operational limitations the tensioning system can be affected with consequences over the integrity of composed elements.

A preventive measure is to reduce the top tension for a short period of time awaiting the normal operational parameters to be reinstalled.

If those conditions are exceeding the acceptable operational limitations the tensioning system can be affected with consequences over the integrity of composed elements.

A preventive measure is to reduce the top tension for a short period of time awaiting the normal operational parameters to be reinstalled.

Another possibility to reduce the wave or currents influence is to modify the positioning of the drilling unit but keeping under control the lower angle of the riser column. The resulted position is meant to keep under control all parameters which may impact the vertical positioning of the riser column which is in fact the mission of the riser management system.

According with aforementioned it is obvious that old methods for keeping the drilling unit on position no long apply. Nowadays, it's unthinkable to run drilling operations in very deep waters without the support of an advanced raiser management system which automatically adjust all operational parameters in order to maintain the integrity of the riser column as well as safety of the drilling operations. If the well head can be considered somehow rigid with regards to the BOP this no longer apply. Depending on the soil characteristics as well as the quality of the cement job for the upper section of the well, the BOP can oscillate with a range between $0-2^{\circ}$ during drilling operations which may cause damages to the drilling equipment as well as increasing the cyclic loads over the well head which will end up with the final fatigue rupture.

The design length of the raiser column is influenced by the environmental conditions by means of the horizontal movement of the drilling unit but also is related with the stroke of the telescopic joint.

During the design stage of the riser column for a given location, the worst case scenario has to be taken in to consideration.

Also, it is recommended to reduce as much as possible the lower flex joint angle trough the positioning system of the drilling unit. Any uncontrolled movement generated by the environmental conditions can generate additional stress over the riser column and finally will impact the well head which can be exposed for early fatigue rupture. Due to the fact that the lower and upper flex joint are not design to absorb the axial movement of the drilling unit these tensions, somehow will impact the tensioning ring and finally, these excessive loads, will impact the tensioning system as well.

Finally, the best way to manage efficiently the riser column, is to keep the positioning of the drilling unit under control within the operational parameters established before starting the drilling program and especially design for a given location with an adequate top tension and this is the big challenge. 


\section{CONCLUSION}

Over the past few years, commercial pressures have come together in something of a perfect storm, so, oil and gas operators are oriented for very deep waters in a bid to sustain production, which equates to higher operating pressures and larger diameter pipe.

However, adding more steel can be expensive and, with the days of long over, it is necessary to find an alternative; one in which total installed cost is a fraction of what it was a couple of years ago.

This article proposes an analysis over the operational conditions encountered during drilling operations. The analysis refers to those factors which are impacting the riser column stability during operations. The results of these factors over the riser column are called riser mechanics. Thus, the objective of the work analyse to which extent the riser column fulfils the applicable API recommendations in force and obtaining theoretical results in this regard for drilling in very deep waters.

The riser column is a complex construction aimed to ensure the connection between the well head and the drilling unit. Evident and, the functions of this assembly are complex and are not limited only to ensure the space necessary for cuttings removal from the well. As the water depth increases, the working conditions of this assembly becomes challenging due to the complex forces and extreme environmental conditions which are impacting the operational mode as well as the stability.

The systems hybrid risers would bring about a more cost effective, technical solutions, and higher productivity providing access to deeper field developments.

Weight and cost savings, as well helping to expand the pressure envelope for applications greater than $15 \mathrm{Ksi}$, the value offered by a shift to non-metallic components in flexible risers will be recognized in multiple areas, most notably:

In very deep water conditions, oil and gas operators want to extend the flexible riser capabilities to larger diameters and higher working pressures - driving the steel content of the cross-section higher, in a spiral of weight inflation. By smart substitution of composite materials, we can reset this pattern, entering a design cycle of positive optimization. Reducing pipe weight means we can load larger volumes on each reel, with fewer vessel transits to port required during an installation campaign.

This paradigm shift also allows the reduction, or in some cases elimination, of buoyancy modules which are required to offset riser weight, meaning that we can facilitate faster offshore installation times, lighter installation vessels, a simpler riser configuration in the water column and overall installed cost savings in the order of $20 \%$.

Integrity management strategies adopted in today's standards and guidelines are in general risk based. The need for follow-up and monitoring of the pipe over its entire lifetime is acknowledged and becoming universally accepted.

The main motivation for a comprehensive integrity management of flexible pipes is to ensure safe and cost effective operation of flexible pipes. Replacement of a pipe is costly, and failure of a flexible pipe may potentially be catastrophic with large economic impact.

Risers, flowlines, fluid transfer lines and jumpers are critical to offshore oil and gas production systems. They are subject to extreme temperatures, pressures, physical stresses and corrosive materials - yet must still ensure reliable connections and optimal product flow. 
As offshore and subsea developments move into very deeper waters, flexible pipe is highly versatile, in some circumstances it is the only suitable technology available.

\section{REFERENCES}

[1] Types of offshore rigs. Available at: https://www.google.ro/search?q=type+platforms+off shore.

[2] Floating productionand subsea systems. Available at: https://www.api.org/oil-and-naturalgas/wells-to-consumer/exploration-and-production/offshore/offshore-production-facilities.

[3] Typical flexible pipe structure and Typical flexible riser structure. Available at: https://www. google.com/search?q=Flexible+risers+and+pipes.

[4] Hybrid Riser System. Available at: www.2hoffshore.com and https://daldidanil.wordpress. com/2016/02/14/flexible-riser.

[5] Typical drilling riser system. Available at: https://www.nap.edu/read/25032/chapter/18\#196

[6] Tudorache, V.P, Avram, L., Antonescu, N.N, s.a.: On the design of the riser columns and their selection criteria, FOREN 2016. Available at: https://www.google.com \& https://www. engstack.com/blog/turrets-moorings-risers-overview.

[7] Tresca and Von Mises. Available at: https://core.ac.uk/download/pdf/52084839.pdf

[8] Morison, J. R., O'Brien, M.P., Johnson, J.W., Schaaf, S.A.: Force exerted by surface waves on piles. Journal of Petroleum Technology. 1950;2

[9] Offshore drilling process (design of a riser system). Available at: https://www.offshoremag.com/dynamic-risers-key-component-for-deepwater-drilling-floating-production.

*** ANSI / API 17J: Specification for Unbonded Flexible Pipe.

*** ANSI / API 17B: Recommended Practice for Unbonded Flexible Pipe, Edition, 2009.

*** Paper No.410, Permeability of Methane, Carbon Dioxide\& Water in PA1I \& PVDF Used for Flexible Pipes, T. R. Andersen, J. I. Skar and C. Hansteen, Norsk Hydro Research Centre, N-3901 Porsgrunn, Norway;

*** ISO 13628-11 Petroleum and natural gas industries - Design and operation of subsea production systems - Part 11 Flexible pipe systems for subsea and marine applications.

*** Avram, L., Troquet, M., Dussap, C.G., Lixandru, G.: Dicţionar de Petrol şi Gaze EnglezRomân-Francez, Edit. Karta-Grafic, Ploieşti, 2008.

*** Avram, L.: Foraj Marin, Edit. Univ. din Ploieşti, 2005.

*** Avram, L., Burlan, A.M: LEXIC Englez-Român-Francez al principalilor termini de ForajExtracţie-Proiectare, Edit. Imprimex, Vol. I 1994 şi Vol. II 1995.

${ }^{* * *}$ Avram, L., Stoica, M., Tudorache, V.P.: Suport de curs universitar - Foraje speciale şi Foraj marin, Platforma de e-Learning a U.P.G. - Ploiesti, 2015.

*** Tudorache, V.P.: Aspecte generale privind exploatările offshore și coroziunea platformelor \& navelor în mediul marin, S.I.P.G. Bucureşti, MPG - ISSN 1583-0322, Nr. 1, 2017.

*** Tudorache, V.P.:Aspecte generale privind optimizarea forajului dirijat prin sistem de sonde multilaterale și creșterea productivității sondelor cu investiții minime, S.I.P.G. Bucureşti, MPG - ISSN' 1583-0322, Nr. 4, 2017.

*** Tudorache, V.P.: Aspecte privind fluidele utilizate la forajul sondelor în zone cu ape adânci, S.I.P.G. Bucureşti, MPG - ISSN 1583-0322, Nr. 2, 2018.

*** Tudorache, V.P., ș.a.: An alternative approach regarding modeling of the gas diffusion in flexible pipelines and risers, used for offshore oil \& gas production; EMERG 5, CNR-CME and AGIR, ISSN 2457-5011, 2017. 